\title{
Ammoniated Forage Poisoning: Concentrations of Alkylimidazoles in Ammoniated Forage and in Milk, Plasma and Urine in Sheep and Cow
}

\author{
By L. Müller, T. Sivertsen* and W. Langseth \\ Departments of Toxıcology and Chemistry, Natıonal Veterinary Institute, Oslo, Norway.
}

4-methylimidazole (4-MeI) has until now been the only identified toxic compound in ammoniated forage considered to be of possible etiological significance in ammoniated forage poisoning. However, several authors have concluded that 4-MeI alone cannot explain the toxicity observed (Morgan \& Edwards 1986, Nielsen et al. 1986, Motoi et al. 1997). On this background, we have examined samples of ammoniated forage and of milk, plasma, and urine collected from ewes and lambs during a previous experimental poisoning study (Sivertsen et al. 1993). We have also studied similar samples from a Norwegian Red Cattle dairy cow fed ammoniated hay for the first 5 days after calving. We have, in addition to the previously known ingredients 4-MeI and 2-methylimidazole (2-MeI), identified 5 new compounds in these samples, all of which were found to be dialkylsubstituted imidazoles: 1,2-dimethylimidazole (1,2-diMeI), 1,4-dimethylimidazole (1,4-diMeI), 1,5-dimethylimidazole $\quad(1,5-$ diMeI), 2,4-dimethylimidazole (2,4-diMeI) and 2-ethyl, 4-methylimidazole (2Et-4MeI) (Müller

* Present address: Dept. of Large Anımal Clinıcal Sciences, Norwegian College of Veterınary Medicıne, P.O.Box 8146 Dep, N-0033 Oslo, Norway. et al. 1998). In this paper we present quantitative measurements of these di- and monoalkylimidazoles in a selection of the collected samples.

The collection of the ammoniated forage and milk samples are described in Müller et al. (1988). The ewe plasma and urine and one of the ewe milk samples were all from the same animal, and were collected after her sucking lamb developed typical ammoniated forage toxicosis. The plasma from her lamb was collected immediately after the onset of acute symptoms. Among the cow samples those collected 2 days postcalving were selected for analysis, because the milk from that day was found to have the highest level of 4-MeI.

The samples were analyzed by gas chromatography with a nitrogen-phosphorous detector (GC-NPD) or by high performance liquid chromatography (HPLC), after cleanup on a strong cation-exchange column. Sample preparation and analytical procedures for the milk and forage samples have been described in detail elsewhere (Müller et al. 1998). In the plasma samples the proteins were precipitated with acetone. Urine samples were extracted 3 times with chloroform/ethanol (4:1). Thereafter, all the samples were purified and analyzed by the same procedure as for milk. 4-MeI was quantified by 
HPLC, the 1-substituted imidazoles by GCNPD, and the 2-substituted imidazoles partly by HPLC and partly by GC-NPD. The average recoveries of alkylimidazoles from forage, plasma and milk were found to be $88 \%, 100 \%$ and $49 \%$, respectively. Recovery in analysis of urine was assumed to be equivalent to that in analysis of plasma. The analytical detection limits were between 0.002 and $0.006 \mu \mathrm{g} / \mathrm{ml}$ in plasma, milk and urine, and $0.2 \mu \mathrm{g} / \mathrm{g}$ in forage.

Table 1 shows the concentrations corrected for recovery of the 7 identified alkylimidazoles in ammoniated forage and in milk, plasma and urine from our 2 feeding experiments.

Results of the determination of 4-MeI in the milk and plasma samples from sheep were in good agreement with previous results for the same material. However, in the samples of ammoniated forage from the sheep experiment, the 4-MeI concentrations obtained in the present study were considerably (ca. $40 \%$ ) lower than previous values, published in Sivertsen et al. (1993). This may indicate some unexpected 4MeI breakdown in the ammoniated seed hay samples during storage, albeit the samples had been kept at $-20^{\circ} \mathrm{C}$, in closed containers, and protected from light.

In the sheep and cow plasma samples, the relative concentrations among the different alkylimidazoles showed a distribution roughly similar to that in the forage samples. The plasma concentrations of 4-MeI represented $0.1 \%-0.5 \%$ of the levels found in the ammoniated forage. This is in good agreement with the results of Friis Kristensen et al. (1991). In the lamb plasma, all concentrations were close to the limit of detection, and only 4-MeI, 2,4diMeI and 2-MeI could be quantified.

In the ewe milk samples, the concentration of 4MeI was 3-4 times higher than in plasma. This is in good agreement with the results of Nielsen et al. (1993). A similar effect was seen for all the alkylimidazoles. This is most probably a re- sult of their chemical properties as weak bases. The even higher transfer of most of the alkylimidazoles into the cow milk sample may partly be a result of species differences, partly of the colostrum character of the cow's milk (Motol et al. 1997). In the cow's milk, the relative distribution among the alkylimidazoles was quite close to the distribution found in the forage. In the ewe milk, however, the concentrations of the other alkylimidazoles were generally higher compared with 4-MeI than they were in the ammoniated seed hay. The effect was strongest for 1,2-diMeI, 1,4-diMeI and 1,5-diMeI. This might be related to the more lipophilic character of the 1-substituted dialkylimidazoles.

With the exception of the surprisingly high level of 1,5-diMeI in the cow's urine, the quantitative distributions between the alkylimidazoles in urine were generally similar to the distributions in forage and in plasma.

The material analyzed in this study was collected from a limited number of animals. However, the good agreement of the alkylimidazole distribution patterns between the different kinds of material collected and between the 2 feeding experiments indicate that the results may be representative for feeding of ruminants with ammoniated timothy hay or seed hay.

Quantitatively, the alkylımidazoles discussed in this paper were the main substances that were found by HPLC and GC analysis in milk and plasma samples from the experimental animals, and not found in the control samples. Judged from the acute toxicity of the dialkylimidazoles in mice (Sivertsen \& Müller, submitted), the content of 2-MeI and dialkylimidazoles reported in this paper does increase the calculated toxicity of the ewe milk with $50-70 \%$, compared to the effect of 4-MeI alone. However, this is far from sufficient to explain the toxicity actually observed in lambs (Sivertsen et al. 1993). Thus, the etiology of ammoniated forage toxicosis is still an enigma. 
Table 1 Concentrations of 1,2-dimethyl-, 1,4-dimethyl-, 1,5-dımethyl-, 2,4-dımethyl-, 2-ethyl-4-methyl-, 2methyl- and 4-methylımidazole in ammoniated seed hay fed to sheep ( $\mu \mathrm{g} / \mathrm{g} \mathrm{DM})$, in plasma, milk and urıne from ewes fed this forage $(\mu \mathrm{g} / \mathrm{ml})$, in plasma from one of their sucklıngs showing symptoms of poisoning $(\mu \mathrm{g} / \mathrm{ml})$; in ammoniated hay fed to a dairy cow $(\mu \mathrm{g} / \mathrm{g} \mathrm{DM})$ and in plasma, milk and urine from this cow, collected 2 days postcalving $(\mu \mathrm{g} / \mathrm{ml})$

\begin{tabular}{lcccccccc}
\hline & \multicolumn{7}{c}{ Compounds } \\
\cline { 2 - 8 } & 1,2-diMeI & 1,4-diMeI & 1,5-dıMeI & 2,4-dıMeI & 2-Et-4-MeI & 2-MeI & 4-MeI \\
\hline Ewes' forage & $<02$ & 1.5 & 1.0 & 126 & 05 & 5.5 & 90 \\
Ewe 1, plasma & $<0002$ & 0.002 & 0.002 & 0.04 & $<0.002$ & 0.01 & 0.07 \\
Ewe 1, milk & 0.02 & 0.07 & 0.04 & 015 & $<0006$ & 0.13 & 023 \\
Ewe 2, milk & 0.03 & 0.07 & 0.03 & 0.20 & $<0.006$ & 0.12 & 0.31 \\
Ewe 1, urine & 0.13 & 0.42 & 0.75 & 7.5 & 0.67 & 3.3 & 21 \\
Lamb of ewe 1, plasma & $<0004$ & $<0004$ & $<0004$ & 0.006 & $<0.004$ & 0.005 & 0.01 \\
Cow's forage & 08 & 0.8 & 0.5 & 34 & 3.2 & 20 & 58 \\
Cow's plasma & $<0.002$ & 0.01 & 0.007 & 0.11 & 0.008 & 0.03 & 0.28 \\
Cow's milk & 0.03 & 0.05 & 002 & 16 & 0.43 & 0.93 & 2.7 \\
Cow's urine & 004 & 022 & 1.6 & 7.3 & 1.1 & 1.5 & 5.8 \\
\hline
\end{tabular}

\section{Aknowledgements}

We are very grateful to Lada Ivanova for her valuable analytical assistance. We also thank Åshild $\mathrm{T}$. Randby and Ottar Kjus in A/S Norsk Forkonservering for providing the ammoniated forage bales; the Laboratory Anımal Unit and the Dept of Reproduction and Forensic Medicine at the Norwegian College of Veterinary Medicıne for their care of the anımals in the feeding experiments; and Are Wiberg in the Department of Chemistry, University of Oslo for the synthesis of the 1,4-dimethyl- and 1,5-dimethylım1dazole standards. This study was carried out with financial support from the Research Counc1l of Norway. A short summary of our research in this field has been presented in a congress poster (Sivertsen et al 1997).

\section{References}

Frils Kristensen V, Enevoldsen C, Witt N, Nielsen P, Kraul I, Frils C, Nielsen TK, Wolstrup C Forgiftnıng forårsaget af ammonıakbehandlet grovfoder (Toxicity of ammoniated roughages). 17. beretnıng, Fællesudvalget for Statens Planteavlsog Husdyrbrugsforsøg, Copenhagen 1991, 41 p

Morgan SE, Edwards WC Pilot studies in cattle and mice to determine the presence of 4-methylimidazole in milk after oral ingestion. Vet. Hum. Toxicol. 1986, 28, 240-242.

Moto Y, Yoshıoka M, Hirose H, Ishino S, Nakajıma Y,
Miyazakı S, Miyamoto S, Sudou M, Manda T, Murai $M$ Central nervous disorder of calves consumıng colostrum containing 4 methyl-ımidazole or colostrum from cows fed excess ammoniated hay JARQ - Jpn Agric. Res Q 1997, 31, 225231.

Miller L, Langseth $W$, Solheim E, Sivertsen T Ammonıated forage poisoning Isolation and characterization of alkyl-substituted imidazoles in ammoniated forage and in milk J Agnic. Food Chem , 1998, 46, 3172-3177

Nielsen TK, Wolstrup C, Witt N, Friss Kristensen V, Kraul I 4-methyl-imidazole in ammoniated roughage Prelımınary investıgatıons. Proceedings; 6th Internat. conf on prod. dis. in farm anım., Belfast Sept 1986, 293-296.

Nielsen P, Frils C, Kraul I, Olsen CE Disposition of 4-methylimidazole in goats and heifers. Res Vet. Sc 1993, 54, 72-79.

Sivertsen T, Langseth $W$, Mo E, Ingebrigtsen $K$ Further arguments against 4-methylimidazole as causal factor in ammoniated forage toxicosis' Experımental seed-hay poisoning in young lambs Acta vet scand. 1993, 34, 227-230.

Sivertsen T, Müller L Ammoniated forage poisoning: Acute toxicity of newly identified dialkylımidazoles tested with a minımal number of inbred mice. (Submitted for publication).

Sivertsen T, Müller L, Solheim E, Langseth $W$ Ammoniated forage poisoning. New alkylımidazoles 
1solated from ammoniated forage and milk concentrations, toxicity to mice and possible sig- nificance. J. Vet. Pharmacol. Ther. 1997, 20, suppl 1, 290-291

(Received July 17, 1998, accepted September 17, 1998)

Reprints may be obtained from: T. Sivertsen, Department of Large Anımal Clınıcal Sciences, Norwegıan College of Veterınary Medicine, P.O. Box 8146 Dep. N-0033 Oslo, Norway. E-mail: tore.sivertsen@veths.no, tel: +47229649 37, fax: +4722964762. 